\title{
Abandoned Quarries in the Akreuch Area (Western Morocco): Inventory of Flora for a Rehabilitation Strategy
}

\author{
Meryem Taoufik ${ }^{1}$, Bouamar Baghdad ${ }^{2}$, Hassan El Hadi', Abdelkader Taleb ${ }^{2}$, \\ Meriem Laghlimi ${ }^{1}$ \\ ${ }^{1}$ Laboratory of Geochemistry, Geomatic and Environment, Hassan II University, Faculty of Sciences Ben M'Sik, \\ Casablanca, Morocco \\ ${ }^{2}$ Department of Natural Resources and Environment, Agronomic and Veterinary Institute Hassan II, Rabat, \\ Morocco \\ Email: meryem.taoufik@gmail.com
}

Received 8 July 2015; accepted 13 August 2015; published 17 August 2015

Copyright (C) 2015 by authors and Scientific Research Publishing Inc.

This work is licensed under the Creative Commons Attribution International License (CC BY). http://creativecommons.org/licenses/by/4.0/

c) (i) Open Access

\section{Abstract}

Quarrying is an activity contributing to the vitality of the Moroccan economy. However, most of these quarries were abandoned at the end of extraction and became dump and later a place of uncontrolled landfills. The number of restored or rehabilitated quarries is limited and this threatens several aspects of the environment, especially, the quality of surface and ground water, landscape, forests, etc. This also gives rise to increased erosion risk. The study identifies plant species covering 10 abandoned quarries in the region of Rabat, especially the Bouregreg River and its affluent Akreuch in order to define a strategy for their restoration or rehabilitation. Field surveys were led to locate and map 10 abandoned quarries and to sample plant species. Herbaria were established and species were identified and classified. The results of the study distinguished 46 different plant species spread over 45 genera and 27 botanical families. The most dominant family in the quarries visited is Asteraceae. These results will allow us to study the vegetation dynamics in these abandoned lands and serve as a basis, in the selection of appropriate species in eventual restoration or rehabilitation projects.

\section{Keywords}

Akreuch, Bouregreg, Flora, Quarries, Rehabilitation, Restoration 


\section{Introduction}

In the Mediterranean countries, extractive activities increase pressure on soil and water resources already limited, which accelerates the process of erosion and subsequent destruction of existing arable lands [1]. The RabatSale-Zemmour-Zaer Region is rich of quarries; according to the national inventory of quarries published by the Ministry of Transport in October 2012 [2], this region counts 117 quarries among the 1885 quarries spread over Morocco. 41\% are abandoned including two quarries declared rehabilitated, $49 \%$ active and $10 \%$ suspended.

Quarry exploitation is defined as a temporary land occupation; rehabilitation must allow the impacted land to regain its former position, or to be intended for a new use. In terms of restoration planning, analysis of the natural regeneration process is a good starting point for the selection of appropriate species to use [3]. Native plants are adapted to the soil, temperature, and the regime of their environment. They are genetically adapted to the local ecology [4]. This study identifies the flora of 10 limestone and marl abandoned quarries in the region of Akreuch and falls within the definition of a strategy for their redevelopment.

\section{Material and Methods}

\subsection{Study Area}

The abandoned quarries explored (Table 1) are located on the Atlantic coast in the Rabat-Sale-Zemmour-Zaer Region and belong to the private domain. They are between the mouth of Akreuch, the dam of Sidi Mohammed Ben Abdellah and the Bouregreg River (Figure 1). The normal average temperatures in the region vary from $7^{\circ} \mathrm{C}$ in winter to $26.4^{\circ} \mathrm{C}$ in summer [5]. The annual rainfall has a normal rate of $560 \mathrm{~mm}$. The study area is characterized by Paleozoic terrains ranging from the Ordovician to Carboniferous with shale, sandstone, quartzite and compact limestone facies; the Cenozoic overlies on the Paleozoic by a major unconformity. Cenozoic materials are represented by Neogene sandstone and marl facies. The sedimentary series underlies Quaternary limestone [6]; (Figure 2).

\subsection{Flora Balance Sheet}

The study of the flora of the 10 abandoned sites is based on field surveys conducted in 2014 (spring/summer). Floristic inventories have been developed in a systematic way in order to be as exhaustive as possible.

The choice of targeted sites is based on their concentration in a sensitive environment because of their proximity to urban areas, the Bouregreg River and its affluent Akreuch. These Quarries are prone to uncontrolled waste sites, which may affect the surrounding areas as they represent a breeding ground for pollution and a risk to the sanitation and the health of neighboring residents and local wildlife.

Field campaigns carried out in the region of Akreuch between the end of May and the end of June 2014 have led to the establishment of a floristic inventory of plant species in 10 abandoned quarries. These quarries were geolocalized and accompanied by a mapping using GIS and satellite images (Landsat 8) dating back to April 2013 and rechecked using a Magellan GPS. The latter has allowed the delimitation of the land concerned and the

\begin{tabular}{|c|c|c|c|c|c|c|}
\hline Quarry & Exploiting & Commissioning & Closing Date & Rock Nature & Area $\left(\mathrm{m}^{2}\right)$ & Municipality \\
\hline $\mathrm{C} 1$ & Med Boudkhil & - & - & Marl & 11,510 & Souissi \\
\hline $\mathrm{C} 2$ & Abassour & - & - & Marl & 7800 & Souissi \\
\hline C3 & Fadil-Dar Dmana & 1978 & 2003 & Limestone & 23,000 & Souissi \\
\hline $\mathrm{C} 4$ & $\begin{array}{l}\text { SDT-SOCAROA } \\
\text { (Ste Doukkala) }\end{array}$ & 1973 & 2007 & Limestone & 157,500 & Oum Azza \\
\hline C5 & SOGECAR & 1969 & 2008 & Limestone & 103,200 & Hssaine \\
\hline C6 & Ste Rougani & 1945 & 2008 & Limestone & 45,800 & Oum Azza \\
\hline C7 & Belahcen & 1959 & 2008 & Limestone & 13,500 & Oum Azza \\
\hline C8 & El Mohami & 1970 & 1992 & Limestone & 57,000 & Oum Azza \\
\hline C9 & $\begin{array}{c}\text { SDT-SOCAROA } \\
\text { (Ste Doukkala) }\end{array}$ & 1975 & 2007 & Limestone & 57,300 & Oum Azza \\
\hline C10 & $\begin{array}{l}\text { SDT-SOCAROA } \\
\text { (Ste Doukkala) }\end{array}$ & 1973 & 2007 & Limestone & 14,500 & Hssaine \\
\hline
\end{tabular}




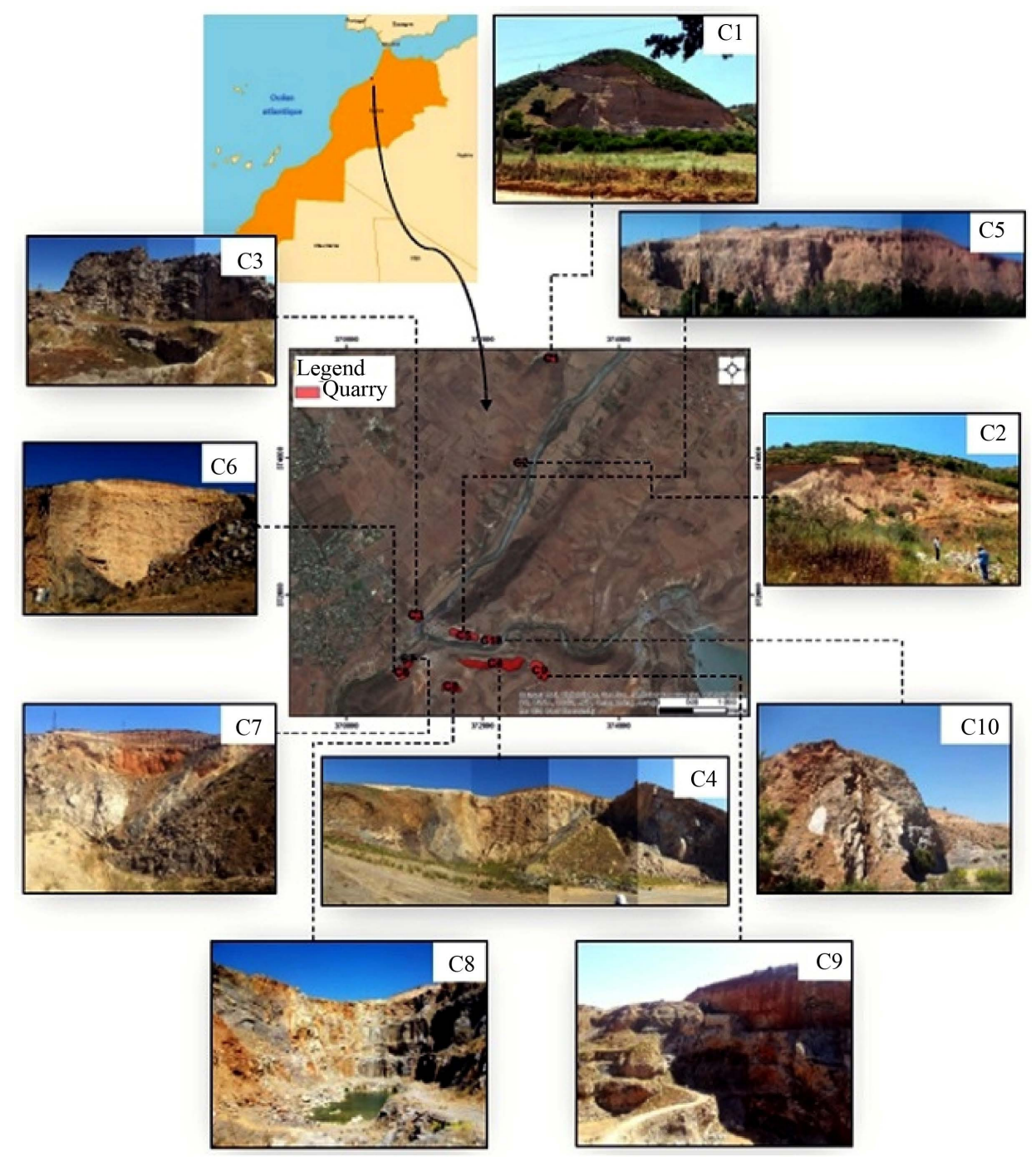

Figure 1. Geographical situation of the studied quarries.

specification of their area that is estimated to $491,100 \mathrm{~m}^{2}$ (Table 1) and also the organization of the different layers of information that formed the basis for the collection of vegetation data.

Quarries surfaces were covered and photos were taken for each collected plant species. The collection was done in a systematic way, herbaria were established and the sampled species growing on the floors and walls of quarries were determined in the Department of Natural Resources and Environment-IAV Hassan II, Rabat (Morocco) and have been classified by quarry, life form, family, genera and class, endemic species and very rare species have been specified according to taxonomic keys and previous studies [7]-[11].

\section{Results and Discussion}

In order to better know the flora colonizing the abandoned quarries, tables of identified species were developed for each quarry including their characteristics (Tables 2-11). The number of species sampled and identified is 130 species.

C1 quarry, located on the right bank of the Bouregreg River, is a former marl quarry, with a height of 43 meters, mostly dominated by the family Asteraceae. Dicotyledons occupy $86 \%$ of the overall total including two endemic species to Morocco; they are listed as very rare and belong to the geographical division MaamouraZemmour-Zaer [9] [10]; it comes to the species Phagnalon saxatile and Centaurium umbellatum (Figure 3). Therophytes are best represented in this quarry (Table 2). 


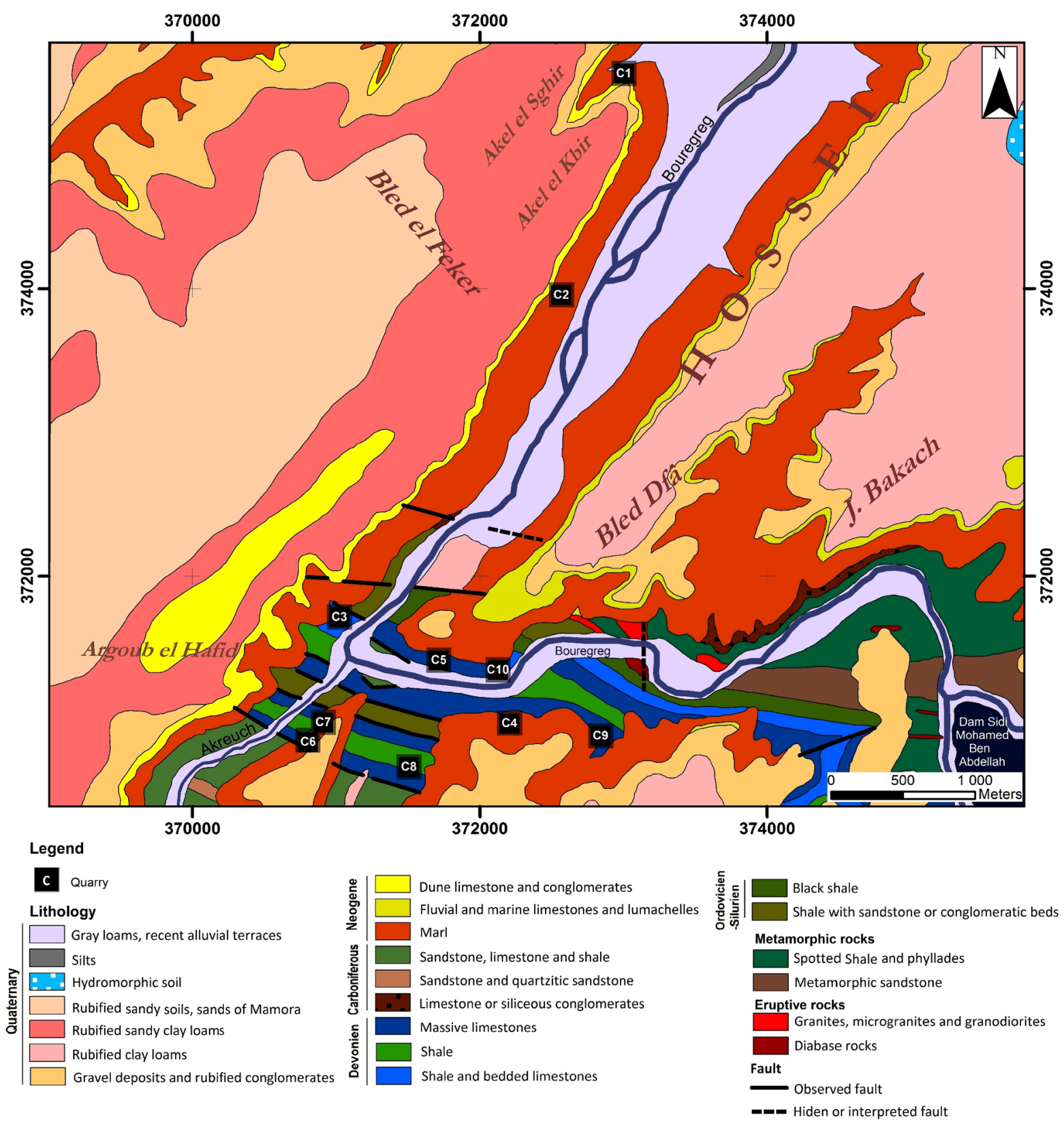

Figure 2. Geology of the study area (According to the geotechnical map of Milliès-Lacroix [6]).

C2 quarry is a former exploitation of marl with a height of about 52 meters, located on the right bank of the Bouregreg River. Surveys carried out in this quarry have revealed 11 different species in which the Asteraceae family ranks first. Dicotyledons are strongly represented and include an endemic species to Morocco classified very rare; the species Phagnalon saxatile. The most common life form in this abandoned land is Therophyte (Table 3).

C3 quarry is an old clay pit, located 40 meters from the Bouregreg River with a height of 70 meters. 23 species were identified, including the species Phagnalon saxatile and the species Centaurium umbellatum; classified very rare and endemic to Morocco, they are specifically associated to the North Atlantic Moroccan geographic division. This division has 200 very rare taxa [9] [10]. The quarry is characterized by the presence of 18 different families of which $83 \%$ belong to Dicotyledons. The most dominant life forms are respectively Hemicryptophyte (8 species) and Phanerophyte (6 species) (Table 4). 


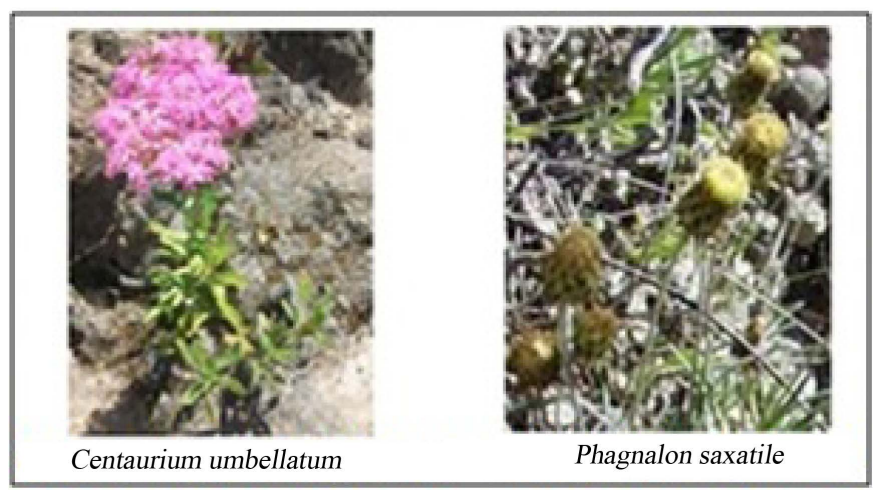

Figure 3. Photos of some rare species of the study area.

Table 2. List of species identified in the quarry C1.

\begin{tabular}{|c|c|c|c|c|c|}
\hline Quarry & Family & Species & Genera & Life Form & Class \\
\hline \multirow{14}{*}{$\mathrm{C} 1$} & Apiaceae & Ammi majus L. & Ammi & Therophyte & Dicotyledons \\
\hline & Asteraceae & Aster squamatus Spreng. & Aster & Hemicryptophyte & Dicotyledons \\
\hline & Asteraceae & Chrysanthemum coronarium L. & Chrysanthemum & Therophyte & Dicotyledons \\
\hline & Asteraceae & Dittrichia viscosa (L.) Greuter & Dittrichia & Chamaephyte & Dicotyledons \\
\hline & Asteraceae & Phagnalon saxatile (L.) Cass. & Phagnalon & Phanerophyte & Dicotyledons \\
\hline & Asteraceae & Scolymus hispanicus L. & Scolymus & Therophyte & Dicotyledons \\
\hline & Chenopodiaceae & Beta macrocarpa Guss. & Beta & Hemicryptophyte & Dicotyledons \\
\hline & Euphorbiaceae & Euphorbia terracina L. & Euphorbia & Therophyte & Dicotyledons \\
\hline & Fabaceae & Trifolium angustifolium L. & Trifolium & Therophyte & Dicotyledons \\
\hline & Gentianaceae & Centaurium umbellatum Gilib. & Centaurium & Therophyte & Dicotyledons \\
\hline & Poaceae & Hyparrhenia hirta (L.) Stapf & Hyparrhenia & Hemicryptophyte & Monocotyledons \\
\hline & Poaceae & Polypogon monspeliensis (L.) Desf. & Polypogon & Therophyte & Monocotyledons \\
\hline & Resedaceae & Reseda lutea L. & Reseda & Therophyte & Dicotyledons \\
\hline & Solanaceae & Nicotiana glauca Graham & Nicotiana & Phanerophyte & Dicotyledons \\
\hline
\end{tabular}

Table 3. List of species identified in the quarry C2.

\begin{tabular}{|c|c|c|c|c|c|}
\hline Quarry & Family & Species & Genera & Life form & Class \\
\hline \multirow{11}{*}{$\mathrm{C} 2$} & Asteraceae & Dittrichia viscosa (L.) Greuter & Dittrichia & Chamaephyte & Dicotyledons \\
\hline & Asteraceae & Phagnalon saxatile (L.) Cass. & Phagnalon & Phanerophyte & Dicotyledons \\
\hline & Asteraceae & Scolymus hispanicus L. & Scolymus & Therophyte & Dicotyledons \\
\hline & Fabaceae & Trifolium angustifolium L. & Trifolium & Therophyte & Dicotyledons \\
\hline & Lamiaceae & Marrubium vulgare L. & Marrubium & Chamaephyte & Dicotyledons \\
\hline & Papaveraceae & Glaucium flavum Crantz & Glaucium & Hemicryptophyte & Dicotyledons \\
\hline & Poaceae & Polypogon monspeliensis (L.) Desf. & Polypogon & Therophyte & Monocotyledons \\
\hline & Poaceae & Vulpia fasciculata (Forssk.) Fritsch & Vulpia & Therophyte & Monocotyledons \\
\hline & Polygonaceae & Rumex pulcher L. & Rumex & Hemicryptophyte & Dicotyledons \\
\hline & Scrophulariaceae & Verbascum sinuatum L. & Verbascum & Hemicryptophyte & Dicotyledons \\
\hline & Solanaceae & Nicotiana glauca Graham & Nicotiana & Phanerophyte & Dicotyledons \\
\hline
\end{tabular}


Table 4. List of species identified in the quarry C3.

\begin{tabular}{|c|c|c|c|c|c|}
\hline Quarry & Family & Species & Genera & Life Form & Class \\
\hline & Apiaceae & Elaeoselinum asclepium (L.) Bertol. & Elaeoselinum & Hemicryptophyte & Dicotyledons \\
\hline & Apiaceae & Torilis arvensis (Huds.) Link & Torilis & Therophyte & Dicotyledons \\
\hline & Asclepiadaceae & Asclepias curassavica L. & Asclepias & Hemicryptophyte & Dicotyledons \\
\hline & Asteraceae & Dittrichia viscosa (L.) Greuter & Dittrichia & Chamaephyte & Dicotyledons \\
\hline & Asteraceae & Phagnalon saxatile (L.) Cass. & Phagnalon & Phanerophyte & Dicotyledons \\
\hline & Caprifoliaceae & Scabiosa atropurpurea L. & Scabiosa & Hemicryptophyte & Dicotyledons \\
\hline & Casuarinaceae & Casuarina L. & Casuarina & Phanerophyte & Dicotyledons \\
\hline & Euphorbiaceae & Ricinus communis L. & Ricinus & Phanerophyte & Dicotyledons \\
\hline & Fabaceae & Trifolium angustifolium L. & Trifolium & Therophyte & Dicotyledons \\
\hline & Gentianaceae & Centaurium umbellatum Gilib. & Centaurium & Therophyte & Dicotyledons \\
\hline & Lamiaceae & Lavandula multifida $\mathrm{L}$. & Lavandula & Chamaephyte & Dicotyledons \\
\hline \multirow[t]{12}{*}{ C3 } & Liliaceae & Asparagus albus L. & Asparagus & Geophyte & Monocotyledons \\
\hline & Moraceae & Ficus carica L. & Ficus & Phanerophyte & Dicotyledons \\
\hline & Plumbaginaceae & Limonium sinuatum (L.) Mill. & Limonium & Hemicryptophyte & Dicotyledons \\
\hline & Plumbaginaceae & Plumbago L. & Plumbago & Hemicryptophyte & Dicotyledons \\
\hline & Poaceae & Hyparrhenia hirta (L.) Stapf & Hyparrhenia & Hemicryptophyte & Monocotyledons \\
\hline & Poaceae & Phragmites australis Trin. Ex Steud. & Phragmites & Geophyte & Monocotyledons \\
\hline & Scrophulariaceae & Verbascum sinuatum L. & Verbascum & Hemicryptophyte & Dicotyledons \\
\hline & Solanaceae & Nicotiana glauca Graham & Nicotiana & Phanerophyte & Dicotyledons \\
\hline & Solanaceae & Solanum sodomaeum L. & Solanum & Chamaephyte & Dicotyledons \\
\hline & Typhaceae & Typha latifolia L. & Typha & Geophyte & Monocotyledons \\
\hline & Urticaceae & Parietaria mauritanica Durieu & Parietaria & Hemicryptophyte & Dicotyledons \\
\hline & Verbenaceae & Vitex agnus-castus L. & Vitex & Phanerophyte & Dicotyledons \\
\hline
\end{tabular}

Table 5. List of species identified in the quarry C4.

\begin{tabular}{|c|c|c|c|c|c|}
\hline Quarry & Family & Species & Genera & Life Form & Class \\
\hline \multirow{10}{*}{ C4 } & Asteraceae & Dittrichia viscosa (L.) Greuter & Dittrichia & Chamaephyte & Dicotyledons \\
\hline & Asteraceae & Phagnalon saxatile (L.) Cass. & Phagnalon & Phanerophyte & Dicotyledons \\
\hline & Asteraceae & Scolymus hispanicus L. & Scolymus & Therophyte & Dicotyledons \\
\hline & Brassicaceae & Diplotaxis catholica (L.) DC. & Diplotaxis & Therophyte & Dicotyledons \\
\hline & Fabaceae & Trifolium angustifolium L. & Trifolium & Therophyte & Dicotyledons \\
\hline & Poaceae & Avena alba Vahl & Avena & Therophyte & Monocotyledons \\
\hline & Poaceae & Vulpia fasciculata (Forssk.) Fritsch & Vulpia & Therophyte & Monocotyledons \\
\hline & Ranunculaceae & Delphinium peregrinum L. & Delphinium & Therophyte & Dicotyledons \\
\hline & Scrophulariaceae & Verbascum sinuatum L. & Verbascum & Hemicryptophyte & Dicotyledons \\
\hline & Solanaceae & Nicotiana glauca Graham & Nicotiana & Phanerophyte & Dicotyledons \\
\hline
\end{tabular}


Table 6. List of species identified in the quarry C5.

\begin{tabular}{|c|c|c|c|c|c|}
\hline Quarry & Family & Species & Genera & Life Form & Class \\
\hline \multirow{12}{*}{ C5 } & Amaranthaceae & Chenopodium murale L. & Chenopodium & Therophyte & Dicotyledons \\
\hline & Asteraceae & Chrysanthemum coronarium L. & Chrysanthemum & Therophyte & Dicotyledons \\
\hline & Asteraceae & Dittrichia viscosa (L.) Greuter & Dittrichia & Chamaephyte & Dicotyledons \\
\hline & Asteraceae & Phagnalon saxatile (L.) Cass. & Phagnalon & Phanerophyte & Dicotyledons \\
\hline & Asteraceae & Scolymus hispanicus L. & Scolymus & Therophyte & Dicotyledons \\
\hline & Myrtaceae & Eucalyptus L’Hér. & Eucalyptus & Phanerophyte & Dicotyledons \\
\hline & Papaveraceae & Glaucium flavum Crantz & Glaucium & Hemicryptophyte & Dicotyledons \\
\hline & Papaveraceae & Papaver rhoeas L. & Papaver & Therophyte & Dicotyledons \\
\hline & Poaceae & Vulpia fasciculata (Forssk.) Fritsch & Vulpia & Therophyte & Monocotyledons \\
\hline & Poaceae & Polypogon monspeliensis (L.) Desf. & Polypogon & Therophyte & Monocotyledons \\
\hline & Scrophulariaceae & Verbascum sinuatum L. & Verbascum & Hemicryptophyte & Dicotyledons \\
\hline & Solanaceae & Nicotiana glauca Graham & Nicotiana & Phanerophyte & Dicotyledons \\
\hline
\end{tabular}

Table 7. List of species identified in the quarry C6.

\begin{tabular}{|c|c|c|c|c|c|}
\hline Quarry & Family & Species & Genera & Life Form & Class \\
\hline \multirow{11}{*}{ C6 } & Asteraceae & Dittrichia viscosa (L.) Greuter & Dittrichia & Chamaephyte & Dicotyledons \\
\hline & Asteraceae & Phagnalon saxatile (L.) Cass. & Phagnalon & Phanerophyte & Dicotyledons \\
\hline & Asteraceae & Scolymus hispanicus L. & Scolymus & Therophyte & Dicotyledons \\
\hline & Juncaceae & Juncus maritimus Lam. & Juncus & Geophyte & Monocotyledons \\
\hline & Papaveraceae & Glaucium flavum Crantz & Glaucium & Hemicryptophyte & Dicotyledons \\
\hline & Poaceae & Avena alba Vahl & Avena & Therophyte & Monocotyledons \\
\hline & Poaceae & Cynodon dactylon (L.) Pers. & Cynodon & Geophyte & Monocotyledons \\
\hline & Poaceae & Hyparrhenia hirta (L.) Stapf & Hyparrhenia & Hemicryptophyte & Monocotyledons \\
\hline & Poaceae & Phragmites australis Trin. Ex Steud. & Phragmites & Geophyte & Monocotyledons \\
\hline & Scrophulariaceae & Verbascum sinuatum L. & Verbascum & Hemicryptophyte & Dicotyledons \\
\hline & Solanaceae & Nicotiana glauca Graham & Nicotiana & Phanerophyte & Dicotyledons \\
\hline
\end{tabular}

Table 8. List of species identified in the quarry C7.

\begin{tabular}{|c|c|c|c|c|c|}
\hline Quarry & Family & Species & Genera & Life Form & Class \\
\hline \multirow{11}{*}{ C7 } & Asteraceae & Dittrichia viscosa (L.) Greuter & Dittrichia & Chamaephyte & Dicotyledons \\
\hline & Asteraceae & Scolymus hispanicus L. & Scolymus & Therophyte & Dicotyledons \\
\hline & Asteraceae & Phagnalon saxatile (L.) Cass. & Phagnalon & Phanerophyte & Dicotyledons \\
\hline & Gentianaceae & Centaurium erythraea Rafn & Centaurium & Therophyte & Dicotyledons \\
\hline & Juncaceae & Juncus maritimus Lam. & Juncus & Geophyte & Monocotyledons \\
\hline & Lamiaceae & Marrubium vulgare L. & Marrubium & Chamaephyte & Dicotyledons \\
\hline & Papaveraceae & Glaucium flavum Crantz & Glaucium & Hemicryptophyte & Dicotyledons \\
\hline & Poaceae & Vulpia fasciculata (Forssk.) Fritsch & Vulpia & Therophyte & Monocotyledons \\
\hline & Polygonaceae & Rumex pulcher L. & Rumex & Hemicryptophyte & Dicotyledons \\
\hline & Scrophulariaceae & Verbascum sinuatum L. & Verbascum & Hemicryptophyte & Dicotyledons \\
\hline & Solanaceae & Nicotiana glauca Graham & Nicotiana & Phanerophyte & Dicotyledons \\
\hline
\end{tabular}


Table 9. List of species identified in the quarry C8.

\begin{tabular}{|c|c|c|c|c|c|}
\hline Quarry & Family & Species & Genera & Life Form & Class \\
\hline \multirow{10}{*}{$\mathrm{C} 8$} & Asteraceae & Centaurea calcitrapa L. & Centaurea & Hemicryptophyte & Dicotyledons \\
\hline & Asteraceae & Dittrichia viscosa (L.) Greuter & Dittrichia & Chamaephyte & Dicotyledons \\
\hline & Asteraceae & Scolymus hispanicus L. & Scolymus & Therophyte & Dicotyledons \\
\hline & Juncaceae & Juncus maritimus Lam. & Juncus & Geophyte & Monocotyledons \\
\hline & Poaceae & Avena alba Vahl & Avena & Therophyte & Monocotyledons \\
\hline & Poaceae & Vulpia fasciculata (Forssk.) Fritsch & Vulpia & Therophyte & Monocotyledons \\
\hline & Poaceae & Cynodon dactylon (L.) Pers. & Cynodon & Geophyte & Monocotyledons \\
\hline & Poaceae & Hyparrhenia hirta (L.) Stapf & Hyparrhenia & Hemicryptophyte & Monocotyledons \\
\hline & Poaceae & Phragmites australis Trin. Ex Steud. & Phragmites & Geophyte & Monocotyledons \\
\hline & Solanaceae & Nicotiana glauca Graham & Nicotiana & Phanerophyte & Dicotyledons \\
\hline
\end{tabular}

Table 10. List of species identified in the quarry C9.

\begin{tabular}{|c|c|c|c|c|c|}
\hline Quarry & Family & Species & Genera & Life Form & Class \\
\hline \multirow{13}{*}{ C9 } & Asteraceae & Dittrichia viscosa (L.) Greuter & Dittrichia & Chamaephyte & Dicotyledons \\
\hline & Asteraceae & Phagnalon saxatile (L.) Cass. & Phagnalon & Phanerophyte & Dicotyledons \\
\hline & Asteraceae & Scolymus hispanicus L. & Scolymus & Therophyte & Dicotyledons \\
\hline & Asteraceae & Silybum marianum (L.) Gaertn & Silybum & Therophyte & Dicotyledons \\
\hline & Fabaceae & Trifolium angustifolium L. & Trifolium & Therophyte & Dicotyledons \\
\hline & Myrtaceae & Eucalyptus L’Hér. & Eucalyptus & Phanerophyte & Dicotyledons \\
\hline & Papaveraceae & Glaucium flavum Crantz & Glaucium & Hemicryptophyte & Dicotyledons \\
\hline & Poaceae & Hyparrhenia hirta (L.) Stapf & Hyparrhenia & Hemicryptophyte & Monocotyledons \\
\hline & Poaceae & Cynodon dactylon (L.) Pers. & Cynodon & Geophyte & Monocotyledons \\
\hline & Poaceae & Avena alba Vahl & Avena & Therophyte & Monocotyledons \\
\hline & Poaceae & Vulpia fasciculata (Forssk.) Fritsch & Vulpia & Therophyte & Monocotyledons \\
\hline & Scrophulariaceae & Verbascum sinuatum L. & Verbascum & Hemicryptophyte & Dicotyledons \\
\hline & Solanaceae & Nicotiana glauca Graham & Nicotiana & Phanerophyte & Dicotyledons \\
\hline
\end{tabular}

Table 11. List of species identified in the quarry C10.

\begin{tabular}{|c|c|c|c|c|c|}
\hline Quarry & Family & Species & Genera & Life Form & Class \\
\hline \multirow{15}{*}{$\mathrm{C} 10$} & Amaranthaceae & Chenopodium murale L. & Chenopodium & Therophyte & Dicotyledons \\
\hline & Asteraceae & Chrysanthemum coronarium L. & Chrysanthemum & Therophyte & Dicotyledons \\
\hline & Asteraceae & Dittrichia viscosa (L.) Greuter & Dittrichia & Chamaephyte & Dicotyledons \\
\hline & Asteraceae & Phagnalon saxatile (L.) Cass. & Phagnalon & Phanerophyte & Dicotyledons \\
\hline & Asteraceae & Scolymus hispanicus L. & Scolymus & Therophyte & Dicotyledons \\
\hline & Myrtaceae & Eucalyptus L’Hér. & Eucalyptus & Phanerophyte & Dicotyledons \\
\hline & Papaveraceae & Glaucium flavum Crantz & Glaucium & Hemicryptophyte & Dicotyledons \\
\hline & Papaveraceae & Papaver rhoeas L. & Papaver & Therophyte & Dicotyledons \\
\hline & Poaceae & Avena alba Vahl & Avena & Therophyte & Monocotyledons \\
\hline & Poaceae & Cynodon dactylon (L.) Pers. & Cynodon & Geophyte & Monocotyledons \\
\hline & Poaceae & Hyparrhenia hirta (L.) Stapf & Hyparrhenia & Hemicryptophyte & Monocotyledons \\
\hline & Poaceae & Phragmites australis Trin. Ex Steud. & Phragmites & Geophyte & Monocotyledons \\
\hline & Poaceae & Polypogon monspeliensis (L.) Desf. & Polypogon & Therophyte & Monocotyledons \\
\hline & Poaceae & Vulpia fasciculata (Forssk.) Fritsch & Vulpia & Therophyte & Monocotyledons \\
\hline & Scrophulariaceae & Verbascum sinuatum L. & Verbascum & Hemicryptophyte & Dicotyledon \\
\hline
\end{tabular}


C4 quarry is the largest one in the study area, called Doukkala, after the name of the company that was exploiting the Devonian limestone. With a height of 70 meters and a length of over 900 meters, C4 has 7 different families including the very rare species Phagnalon saxatile, and the species Diplotaxis catholica endemic to Morocco and the Iberian Peninsula. The latter is classified as extinct or with a dubious presence (Figure 4) and belongs to the Brassicaceae family.

The class of Monocotyledons is not widespread: only two species of the Poaceae family: Avena alba and Vulpia fasciculata belonging to the Therophyte life form (Table 5).

C5 quarry is an abandoned limestone farm situated on the left bank of the Bouregreg River in the Hssaine municipality. With a height of 65 meters, this quarry is occupied by 7 different families with $83 \%$ belonging to the Dicotyledons class and is mostly dominated by the Therophyte life form. Phagnalon saxatile species has been recorded in this quarry (Table 6).

C6 is a former limestone quarry with a height of 70 meters, mostly occupied by the Poaceae family followed by the Asteraceae family. Dicotyledons class is the most present with a rate of $55 \%$. It is noted in this quarry that the life form Hemicryptophyte and Geophyte are the most important with the same attendance rate. The quarry also recorded the species Phagnalon saxatile (Table 7).

C7 is a former limestone quarry, with a height of 60 meters. Its exploitation affected the water table which favored the appearance of some species typical of wetlands [12] (Figure 5); Juncus maritimus of the Juncaceae family, Marrubium vulgare of the Lamiaceae family and Rumex pulcher of the Polygonaceae family.

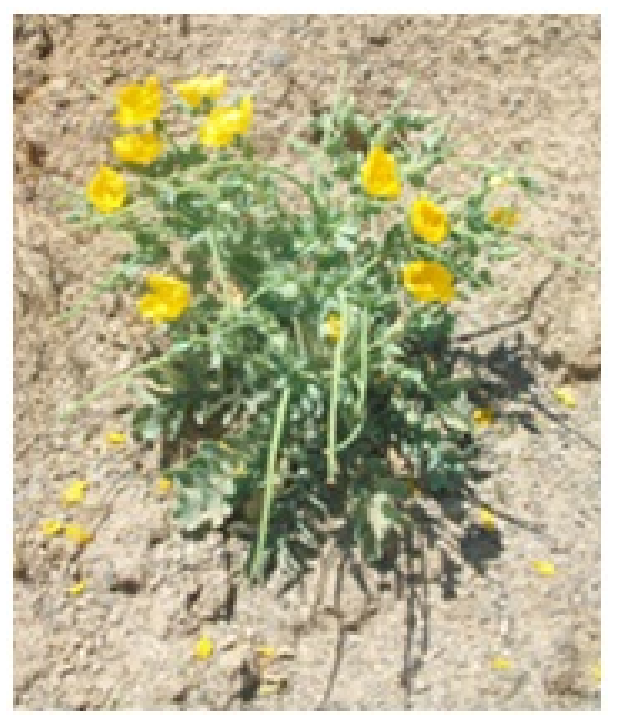

Figure 4. Photo of Dipolataxis catholica.

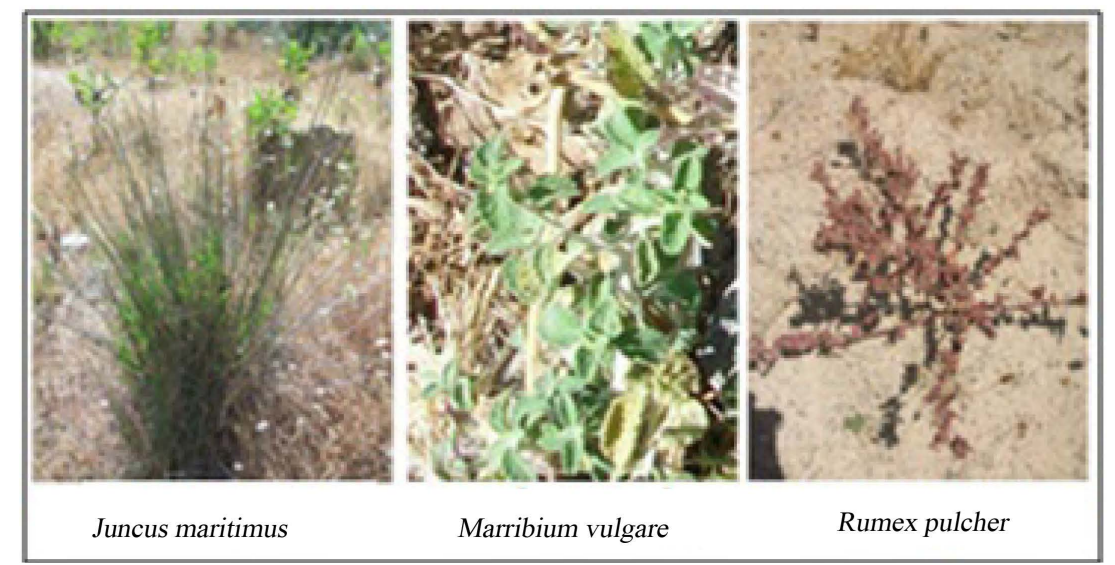

Figure 5. Photos of some species typical of wetlands. 
The quarry counts 9 different families in which Asteraceae is the most dominant, two species classified very rare and endemic to Morocco, namely the species Phagnalon saxatile of the Asteraceae family and Centurium erythraea of the Gentianaceae family. Therophytes and Hemicryptophytes are best represented in this quarry (Table 8).

The former limestone quarry C8 reaches 50 meters in height. The extraction exposed the water table and spawned the emergence of a source in the quarry, which has promoted the development of some hygrophilous species Juncus maritimus, Phragmites australis and Centaurea calcitrapa [13]. Families showing the largest number of species are Poaceae followed by Asteraceae. Monocotyledons are best represented in this quarry with a rate of $60 \%$ of the overall total (Table 9 ).

C9 quarry is a former limestone exploitation of a height of 70 meters, dominated by Asteraceae and Poaceae. The life form Therophyte is the most common ( 5 species from a total of 13 species). Dicotyledons are strongly represented including the very rare species Phagnalon saxatile (Table 10).

$\mathrm{C} 10$ is an abandoned limestone quarry about 30 meters high. Asteraceae and Poaceae represent two-thirds of the overall total that includes the species typical of wetlands: Cynodon dactylon, Phragmites australis and Polypogon monspeliensis of Monocotyledons class. In more or less dry areas of the quarry, species Polypogon monspeliensis is gaining ground; this plant is pollinated by wind and water and is transported by wool and skin of animals [14]; (Table 11).

\subsection{Results and Discussion}

Statistical analysis conducted on the resulting tables shows that the Asteraceae is the most dominant with 34 species and 34 genera of the flora of the 10 quarries (26\% of the overall total), followed by Poaceae with 30 species and 30 genera (23\% of the overall total). The latter is leading in the ranking of the flora of Moroccan wetlands [15]. The family that occupies the $3^{\text {rd }}$ rank is Solanaceae with 10 species and 10 genera ( $8 \%$ of the overall total); (Figure 6). The first three families of Moroccan vascular flora are always identical and in the same order: Asteraceae, Fabaceae and Poaceae. They totalize 1329 species, which is over a third of the national specific inventory [10]. In the elaborated inventory, the order is different; the family Fabaceae occupies the $5^{\text {th }}$ rank with 5 species and 5 genera ( $4 \%$ of the overall total) after the families Papaveraceae and Scrophulariaceae with 8 species and 8 genera (6\% of the overall total) each.

Dicotyledons, the best ranked class, include 95 species belonging to 36 different genera and 23 different families while Monocotyledons class is present with 9 species belonging to 9 different genera and 4 different families.

The species recorded in all quarries is Dittrichia viscosa. This plant, mainly distributed in the western Mediterranean countries, [16] is present in degraded sites [4]. Species Nicotiana glauca, Scolymus hispanicus and Phagnalon saxatile are recorded in 9 quarries, while other species are recorded in less than 9 quarries.

\subsection{Systematic Aspect}

Quarries that recorded the highest number of different species are C3 (23 species, 23 genera and 18 families all

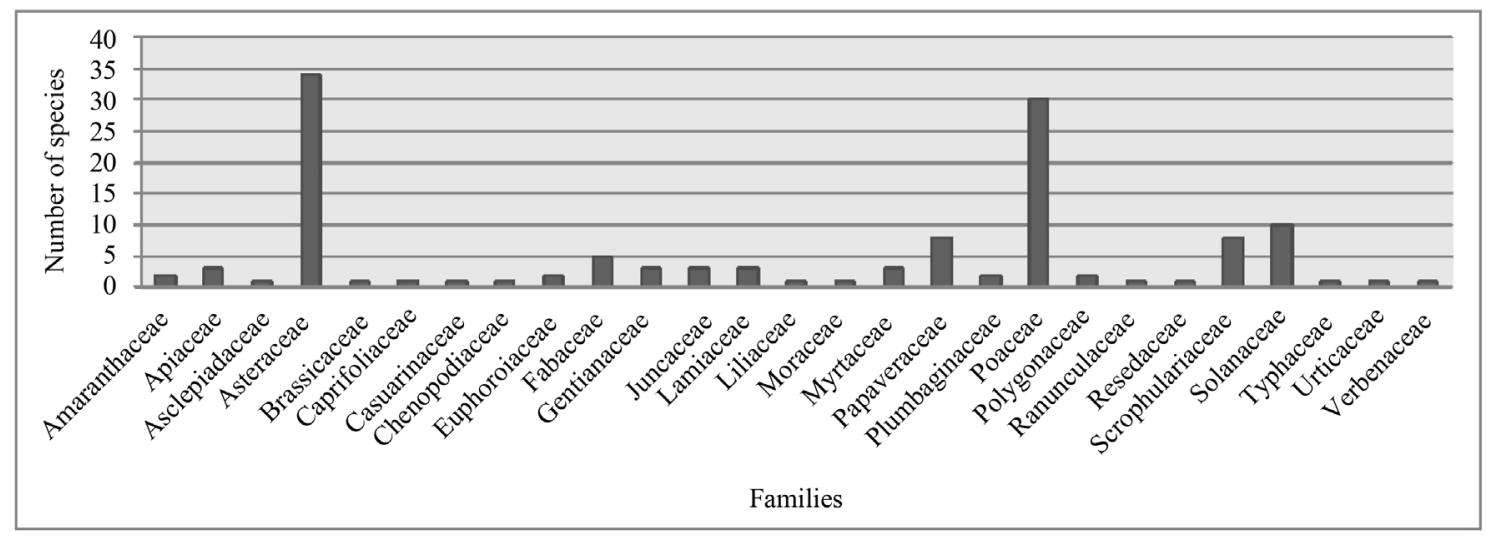

Figure 6. Ranking of families by number of species in the 10 abandoned quarries. 
different), followed by C10 (15 species, 15 genera and 6 families all different). Other quarries have less than 15 different species (Figure 7 and Figure 8).

The class of Dicotyledons dominates in all the quarries except C8 quarry where the class of Monocotyledons dominates with $60 \%$ of the overall total (Figure 9).

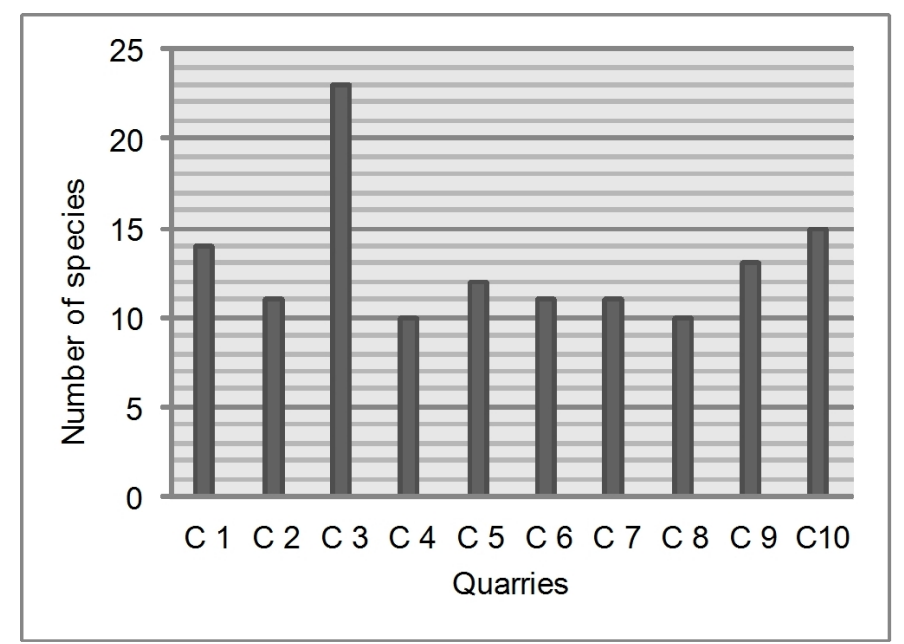

Figure 7. Number of different species by quarry.

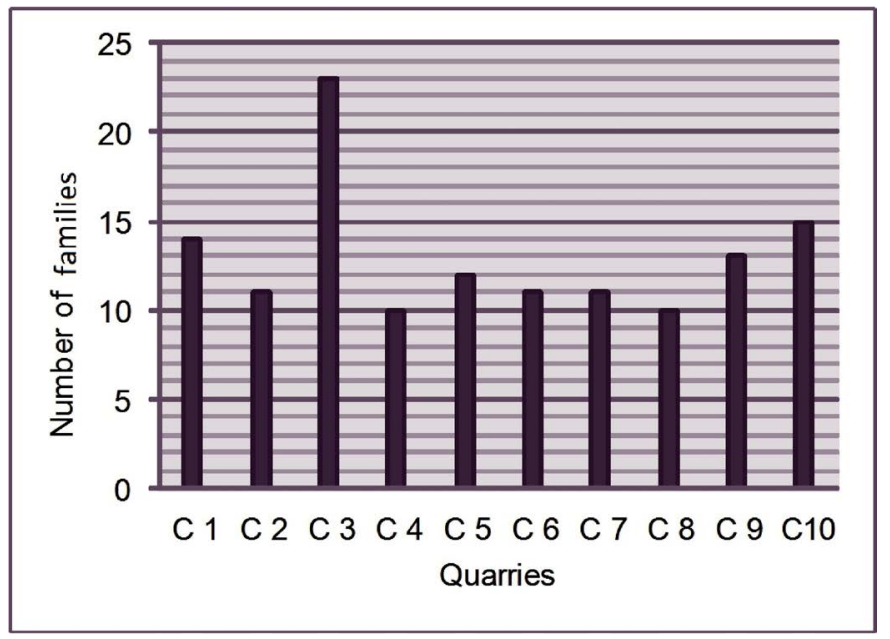

Figure 8. Number of different families by quarry.

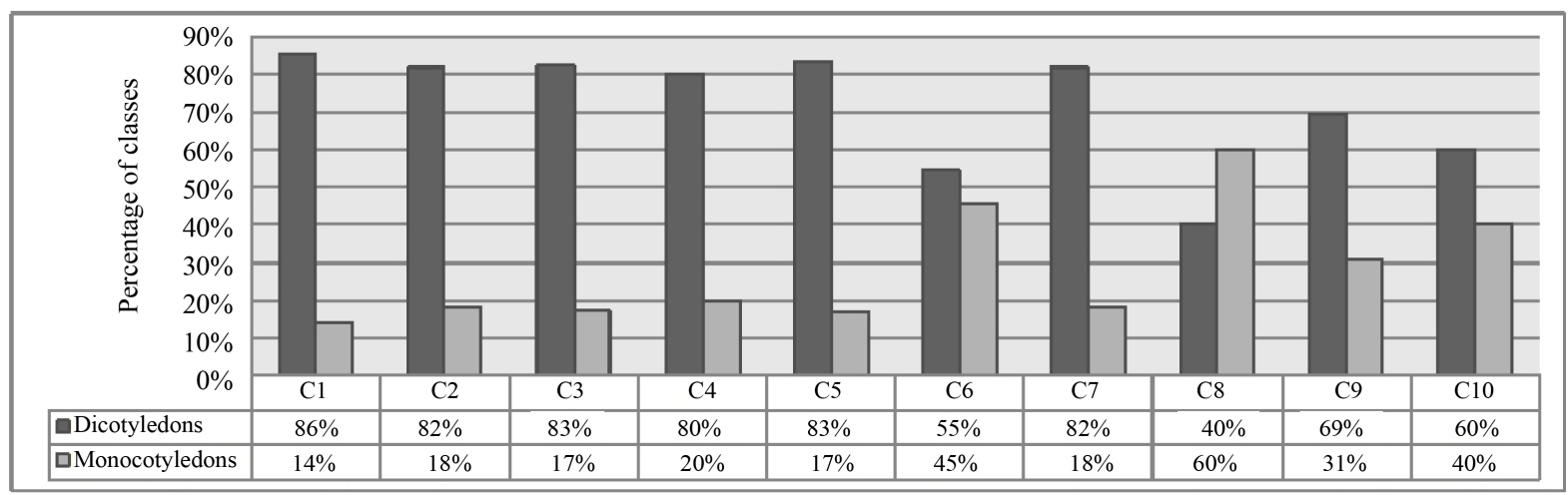

Figure 9. Percentage of classes in the 10 quarries. 
The life forms of identified species were classified according to the Raunkiaer system [17]. The latter classifies plants according to the position of their perennating buds in relation to the soil surface and also to their adaptation to unfavorable seasons. According to the spectrum of life forms (Figure 10), it is evident that the type Therophyte is the predominant and is represented by $36 \%$ of the total flora. The type Hemicryptophyte represents $24 \%$ of all species; these two types characterize the flora of Moroccan wetlands [15]. The Phanerophytes represent $19 \%$, the Chamaephytes $11 \%$ and the Geophytes $10 \%$ of total flora.

Quarries that sheltered the largest number of species of Therophyte are C1 (8 species), C10 (7 species), C4 (6 species) and C5 (6 species). The Hemicryptophyte life form is more dominant in the C3 quarry (8 species) followed by Phanerophyte (6 species) whereas it doesn't exceed 3 species in other quarries. No Geophyte species were found in C1, C2, C4 and C5 (Figure 11).

\subsection{Environmental and Ecological Aspects}

From the results, the most dominant species is Dittrichia viscosa of the Asteraceae family, many studies have shown that this plant grows in limestone or silica sol [18], it often locates in abandoned lands, on rocky coasts or screes of mountains, and it is characterized by a pioneering character when there is no competition among plants [16], followed by Nicotiana glauca known for its productivity of large amounts of seeds easily dispersible by the wind and for its resilience to a broad range of environmental conditions [19], Phagnalon saxatile the very rare species endemic to Morocco having a preference for calcareous soils [20], and Scolymus hispanicus which is common in poor soils waste places and abandoned agricultural lands [21].

The proximity of the Bouregreg River and its affluent Akreuch as well as the accumulation of rainwater and the attainment of the water table have favored the emergence of a few native wetland plants: Marrubium vulgare, Scabiosa atropurpurea, Phragmites australis, Typha latifolia, Vitex agnus castus, Juncus maritimus and Cynodon dactylon.

Therophytes have registered a large presence in the entire inventoried flora; this life form has an invader character and represents an indicator of hyperdegradation [22] [23].

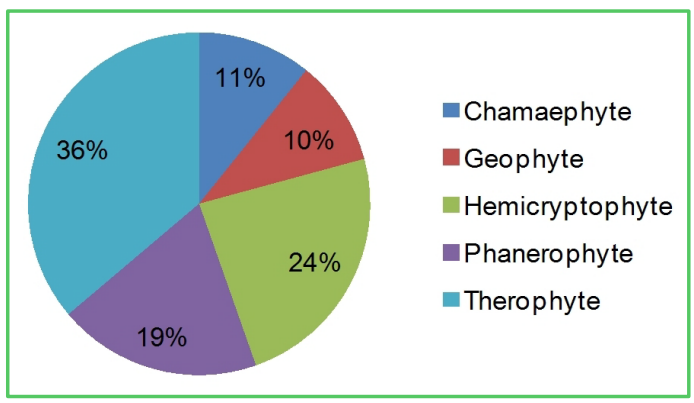

Figure 10. Spectrum of life forms in the 10 quarries.

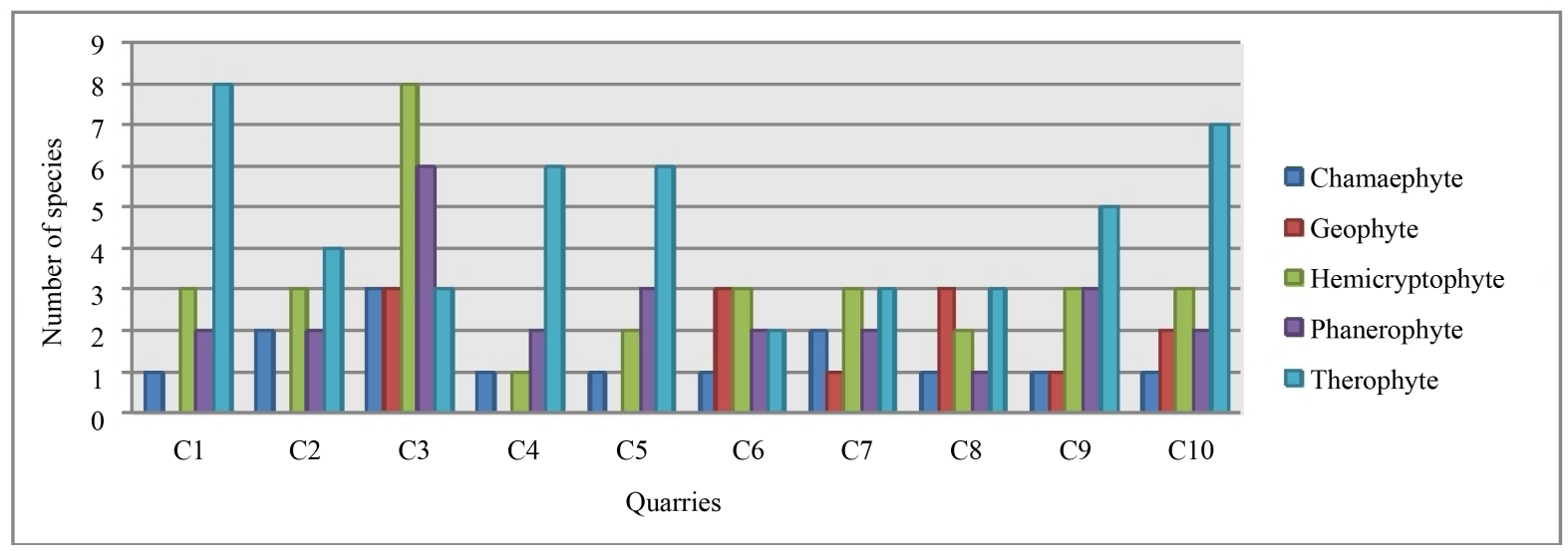

Figure 11. Distribution of life forms by quarry. 


\section{Conclusion}

From botanic studies conducted, it can be concluded that:

1) Quarries shelter several plants with characteristics of Mediterranean species.

2) The majority belongs to the families Asteraceae and Poaceae that occupy $49 \%$ of the flora of all quarries, followed by Solanaceae, Scrophulariaceae, Papaveraceae and Fabaceae.

3) The frequency of the dominance of some species is explained by the ease of dispersion of their seeds by wind or animals.

4) The existence of the Bouregreg River and its affluent Akreuch contribute to biodiversity in this region.

5) The floristic analysis has revealed that $73 \%$ of the species inventoried are part of the Dicotyledons class and the life forms Therophyte (36\%) and Hemicryptophyte (24\%). Dicotyledons are largely dominant with 95 species including very rare, extinct or with a dubious presence species.

\section{References}

[1] Darwish, T., Khater, C., Jomaa, I., Stehouwer, R., Shaban, A. and Hamze, M. (2011) Environmental Impact of Quarries on Natural Resources in Lebanon. Land Degradation \& Development, 22, 345-358. http://dx.doi.org/10.1002/ldr.1011

[2] Anonyme (2012) Inventaire national des carrières (Direction des Affaires Administratives et Juridiques, Trans.): Ministère de l'Equipement et du Transport.

[3] Khater, C., Martin, A. and Maillet, J. (2003) Spontaneous Vegetation Dynamics and Restoration Prospects for Limestone Quarries in Lebanon. Applied Vegetation Science, 6, 199-204.

[4] Martin, A., Khater, C., Mineau, H. and Puech, S. (2002) Rehabilitation Ecology by Revegetation. Approach and Results from Two Mediterranean Countries. Korean Journal of Ecology, 25, 9-17.

[5] Bounouira, H. (2007) Etude des qualités chimiques et géochimiques du bassin versant de Bouregreg. Geochemistry thesis, Université Pierre et Marie Curie, Paris.

[6] Milliès-Lacroix, A. (Cartographer) (1974) Carte géotéchnique de la région de Rabat. Notes et Mémoires, 238.

[7] Sauvage, C. and Vindt, J. (1952) Flore du Maroc: analytique, descriptive et illustrée. Editions Internationales, Série Botanique 4, Travaux de l'Institut Scientifique Chérifien, Tanger.

[8] Ennabili, A. and Ater, M. (1996) Flore (Pteridophyta et Spermatophyta) des zones humides du Maroc Mediterraneen: Inventaire et Ecologie. Acta Botanica Malacitana, 21, 221-239.

[9] Fennane, M. and Ibn Tattou, M. (1998) Catalogue des plantes vasculaires rares, menacées ou endémiques du Maroc. Bocconea, 8, 5-11.

[10] Fennane, M. and Ibn Tattou, M. (1999) Observations sur la flore vasculaire endémique, rare ou menacée du Maroc. Flora Mediterranea, 9, 113-124.

[11] Dalimi, M., Baghdad, B., Zakarya, D., Taleb, A. and Carlos Iñigo Iñigo, A. (2014) Vegetations as Biodeterioration Agents on Archaeological Stones: Comparative Study of Plant Species Found on the Walls of Some Moroccan Historical Monuments. Journal of Research in Agriculture, 3, 193-204.

[12] Hammada, S. (2007) Etudes sur la végétation des zones humides du Maroc: Catalogue et Analyse de la Biodiversité Floristique et Identification des principaux Groupements Végétaux. (Biologie). Faculté des Sci., Université Mohamed V, Agdal.

[13] Ennabili, A. and Gharnit, N. (2003) Effets d’amenagements du littoral tétouanais (Nord-Ouest du maroc) sur la végétation hygrophile (Spermatophyta). Acta Botanica Barcinonensia, 48, 199-216.

[14] Guertin, P. (2003) Factsheet for: Polypogon Monspeliensis (L.) Desf. USGS Weeds in the West Project: Status of Introduced Plants in Southern Arizona Parks. U.S. Geological Survey/Southwest Biological Science Center, Tuscon, 24 p.

[15] Hammada, S., Dakki, M., Ibn tattou, M., Ouyahya, A. and Fennane, M. (2004) Analyse de la biodiversité floristique des zones humides du Maroc. Flore rare, menacée et halophile. Acta Botanica Malacitana, 29, 43-66.

[16] Brullo, S. and De Marco, G. (2000) Taxonomical Revision of the Genus Dittrichia (Asteraceae). Portugaliae Acta Biologica, 19, 341-354.

[17] Raunkiaer, C. (1905) Types biologiques pour la géographie botanique. Kongelige Danske Videnskabernes Selskabs Forhandlinger, 5, 347-438.

[18] Wacquant, J.P. and Baus Picard, J. (1992) Nutritional Differentiation among Populations of the Mediterranean Shrub Dittrichia viscosa (Asteraceae) in Siliceous and Calcareous Habitats. Oecologia, 92, 14-22. http://dx.doi.org/10.1007/BF00317257 
[19] Bogdanovic, S., Bozena, M., Ruscic, M. and Dolina, K. (2006) Nicotiana glauca Graham (Solanaceae), a New Invasive Plant in Croatia. Acta Botanica Croatica, 65, 203-209.

[20] Oliveira, G., Clemente, A., Nunes, A. and Correia, O. (2014) Suitability and Limitations of Native Species for Seed Mixtures to Re-Vegetate Degraded Areas. Applied Vegetation Science, 17, 726-736. http://dx.doi.org/10.1111/avsc.12099

[21] Polo, S., Tardío, J., Vélez-del-Burgo, A., Molina, M. and Pardo-de-Santayana, M. (2009) Knowledge, Use and Ecology of Golden Thistle (Scolymus hispanicus L.) in Central Spain. Journal of Ethnobiology and Ethnomedicine, 5, 42. http://dx.doi.org/10.1186/1746-4269-5-42

[22] Barbero, M., Quezel, P. and Loisel, R. (1990) Les apports de la phytoécologie dans l'interprétation des changements et perturbations induits par l'homme sur les écosystèmes forestiers méditerranéens. Forêt Méllitertanéenne, 3, 194-215.

[23] Dabgar, Y.B., Solanki, H.A., Mali, M.S. and Khokhariya, B.P. (2010) Plant Diversity and Its Life Forms of Visnagar Talika (N. GUJ.), India. Plant Archives, 10, 589-593. 